\title{
Research on Improving the Quality of Scientific Research Management Team in Colleges and Universities
}

\author{
Jinming Liu \\ Scientific Research Department \\ Zhongnan University of Economics and Law \\ 430073 China
}

\begin{abstract}
As the main organizer and service provider of scientific research activities in colleges and universities, the quality and business ability of scientific research management team plays a basic role in the effectiveness and quality of scientific research management in colleges and universities. By analyzing the current situation of scientific research management in colleges and universities in China, this paper finds out the main factors that restrict the improvement of the performance of scientific research management in colleges and universities, points out the professional qualities and skills that scientific research managers should possess, and probes into the methods and ways to improve the quality of scientific research manage ment team in colleges and universities.
\end{abstract}

Keywords-Scientific research in colleges and universities; Management team; Quality improvement

\section{INTRODUCTION}

In September 2014, Premier Li Keqiang issued the slogan of "mass entrepreneurship and innovation" at the World Economy Forum in Davos, Switzerland. He pointed out that we should set off a new wave of "mass entrepreneurship and grassroots entrepreneurship" on the land of 9.6 million square kilometers in China, and form a new trend of "mass innovation and everyone innovation". Colleges and universities undertake the important historical missions of talent training, scientific research, social service and cultural heritage and innovation, while the scientific research is an inexhaustible motive force for the continuation, development and innovation of colleges and universities. With the rapid development of the national economy and society, the state's investment in scientific and technological innovation has also increased year by year. As the frontier of scientific and technological innovation, colleges and universities have obtained a large amount of scientific research funds, which greatly promote the development of scientific research in colleges and universities, and the scientific research undertakings of colleges and universities have entered a new period of development. In the new era, new demands have been put forward to the management team of scientific research in colleges and universities. We must bring out our strengths to make up for our weaknesses, and consolidate the management system mechanism, the knowledge structure of the managers, the methods of management and the means of information, so that we can live up to the expectations of the new area.

\section{Current Situation of Scientific Research MANAGEMENT IN COLLEGES AND UNIVERSITIES}

Colleges and universities undertake a large number of scientific research tasks of national scientific and technological innovation, and are the new force of scientific and technological innovation. The increasing workload of scientific research also brings new problems to scientific research management in universities. Faced with the new situation, it is imminent to reform the obsolete, unreasonable and inefficient management mode that impedes the development of scientific research in colleges and universities. Innovating the new mode of service instead of management is the way out for scientific research management in colleges and universities. Therefore, at present, what is the current situation of scientific research management in colleges and universities, what are the factors that restrict the improvement of the efficiency of scientific research management and the quality of scientific research management, and what is the position of the professional qualities of scientific research management team in the management of scientific research in colleges and universities? This article will strive to clarify these relationships, and find the breakthrough point of the reform of the scientific research management of colleges starting from improving the professionalism of management team.

According to the author's observation, there are several problems in the management of scientific research in colleges and universities in our country at present:

\section{A. Research Managers Lack Knowledge and Business Skills}

As we all know, the modern society is the age of knowledge economy. Economy, society and science and technology are developing rapidly. The rapid development of cross-disciplines and technical integration and the continuous emergence of new disciplines greatly promote the development of the scientific research, which also requires a large number of high quality scientific research service teams that understand science and technology, information technology and management to provide a valuable and powerful support for scientific research workers. However, the 
reality is that the scientific research management team in China's colleges and universities is not yet ready for ideological or institutional construction and skills reserve, and is in a state of passive adaptation. In terms of language, many researchers are unable to master a foreign language, so they are hard to connect with the world, and researchers can't track the forefront of science and technology and research trends, not to mention the focus on the direction and subject of research. In terms of the information technology, many researchers can only make use of computers and some simple operating systems, and can't make use of the system from large data to cultivate scientific research stars, create scientific research teams and cultivate major projects. Their market awareness and the concept of intellectual property protection are poor, and the system is not sound[1]. They lack the ability to accurately grasp the market demand, are free from the market, do not understand the market quotation, the national and local actual needs, and the laws and regulations, especially the intellectual property law, and can't provide market access points and legal basis for the transformation of teachers' scientific and technological achievements.

\section{B. Scientific Research Management Method is Single, and the Process Management Lags Behind}

At present, the management of scientific research in universities shows the following characteristics: First, the workload of scientific research is greatly increased, while scientific research management is still on the track of the old rhythm, unable to keep pace with quantitative change and lagging behind in service. Second, cross-disciplines and emerging discipline are developing rapidly, but the scientific research management still adopts inherent mode, which not only does not help the development of new things, but also hinders the progress of new things. Third, scientific research projects in colleges and universities increase a lot, but process management lags behind. In order to produce high level scientific research achievements, we must strictly enforce the process management of scientific research projects[1]. All of these are related to the single way of scientific research management, inherent mode and low degree of informationization. In project management, there is a great deal of practice in terms of paying attention to the project approval but despising project summary, paying attention to quantity but despising quality, and paying attention to theory but despising application, which is closely related to lack or lag of process management.

\section{Scientific Research Management is Fragmented, and the Comprehensive Ability of Managers Needs to be Improved}

Scientific research management is a complex open system involving people, money and goods. At present, the management of scientific research in colleges and universities in China is mainly based on the independent operation of scientific research, finance, audit, equipment and achievement transformation of the school level departments. Although they are interconnected, it is mainly shown as a rigid connection[3]. However, for most of the time, they are separated from each other. They stand on the departmental standpoint to publish and explain policies, so it is difficult to form a joint effort conducive to scientific research. Because of the lack of comprehensive ability of scientific research managers, such as lack of skillful communication skills, lack of professional qualities, lack of concise analysis ability, and so on, the management efficiency is low, and they can't find the key points in the research work.

\section{Professional Quality of Scientific Research MANAGEMENT TEAM IN COLLEges AND UnIVERSITIES}

In order to meet the new requirements for scientific research management in the new era, the scientific research management team of universities should have the following basic professional qualities:

\section{A. Good Knowledge Structure and Rich Knowledge Reserve}

The cultivation and public relations of major subjects, the formation of important scientific research teams, and the output of important scientific research achievements require the cooperation and support of high-quality scientific research service teams, which also urge the birth of high-quality scientific research team. The scientific research management team in colleges and universities must have certain professional basic knowledge and language skills, can master a foreign language, can help teachers to participate in international project cooperation, and can be proficient in retrieval and use of international journal papers. They should have the knowledge of pedagogy, behavioral science, modern psychology, management and so on, have good market control and intellectual property background knowledge, and can promote the transformation of scientific and technological achievements.

\section{B. Management Innovation Ability in the Information Age}

The object of scientific research management in colleges and universities is the talents with high level of knowledge. The ultimate goal of the scientific research personnel is innovation. Only the scientific research managers who have the consciousness of management innovation can adapt to the needs of scientific and technological innovation and make scientific research management work integrated with the innovative spirit of scientific research personnel[4]. Nowadays, the society is the digital, network and information age. We can't satisfy the basic work of simple report statistics, data preservation, and information release and so on. We must be brave and good at using information network to collect knowledge, track the frontier and provide basic scientific research support for teachers. Moreover, we should make full use of big data to carry out scientific research management innovation, allocate resources for scientific research projects, research team building, and scientific research direction and so on, coordinate international and domestic scientific research resources, coordinate the scientific research resources in school and outside school, and optimize the allocation of resources.

\section{Skilled Coordination and Management Ability}

In the face of complex and complicated scientific research management, scientific research managers must have certain organizational, coordination, cognitive and reaction abilities, 
of which, the ability to communicate and coordinate is especially important. They need to coordinate the relevant functional departments within the school, and coordinate the scientific research workers, relevant functional departments inside and outside school and enterprises and institutions. In this sense, the scientific research managers are liaison men and messengers. They must have lofty professional ethics, humble working attitude and good communication ability. Research management personnel are based on "management" to carry out service work, which is the driving force to better complete the job. Only by mastering a certain art of management and applying the methods and theories of scientific management to the work, can the scientific management personnel clear their thoughts, seize the key and carry out the management work in an overall way[5].

IV. The Means of Improving the Professional Quality of THE SCIENTIFIC Research Management Team in Colleges AND UNIVERSITIES

\section{A. The Cultivation of Knowledge System}

In a sense, the quality of the grass-roots staff determines the management level of the university. Therefore, colleges and universities must establish a system of continuing education and establish a long-term mechanism for vocational skills training, list the training plan, content, location and cycle according to the actual needs of the post of scientific research management, give full play to their own discipline advantages, invite relevant professional teachers in and outside school, and carry out pertinent training for front-line research management teams in schools and institutes in order to enrich their knowledge and consolidate their business basis. At the same time, schools must establish a system of attendance and assessment, be based on actual results, and give them organizational guarantees, so as to prevent them from becoming mere formality and giving up halfway.

\section{B. Cultivation of Modern Management Ability}

The scientific research managers in colleges and universities should also have the inherent requirement of selflearning and self enhancement, and train their own modern management skills and abilities. The first point is to strengthen the learning and updating of management knowledge, to understand the latest management methods and techniques at any time, to improve the management mode and to enrich the management practice in combination with the job. The second point is to strengthen the study of foreign languages, master a foreign language, mainly English, to be able to read and use foreign documents skillfully, and to study the research overview and frontier issues of related subjects. The third point is to strengthen the learning of information technology, to apply the relevant scientific research information system skillfully, to skillfully use the big data of scientific research and the office automation software, and to improve the ability of using the network to carry out modern scientific research management.

\section{Establishing an Effective Evaluation of the Comprehensive Quality of Scientific Research Managers and optimizing the management mode}

When all rules and regulations and management process are perfected, scientific research managers become the decisive factors for the efficiency of scientific research management and the improvement of scientific research quality, and the key to the smooth development of scientific research undertakings. In modern human resources management, personnel quality assessment is an important technology[6]. A set of comprehensive quality evaluation system for scientific research managers should be established. According to the evaluation analysis report and the advantages of individual management, the classification management should be carried out, so as to make the best use of everything and everyone. The comprehensive quality evaluation items of the scientific research managers should be institutionalized and normalized. The periodic comprehensive quality assessment can objectively analyze the technical indexes such as business skills, knowledge reserve and psychological state for a certain period of scientific research managers, and can analyze the advantages and weaknesses of the managers, which lays a solid foundation for further training work.

\section{Conclusions}

In short, scientific research managers play a vital role in the management of scientific research in colleges and universities. The comprehensive use of high-quality scientific research management team and modern management means is the fundamental guarantee for improving the efficiency and the quality of scientific research in universities. Colleges and universities should ensure the job training, skills improvement and professional title evaluation to improve the comprehensive quality of scientific research managers, so as to ultimately promote the improvement of scientific research management efficiency and the qualitative leap in scientific research quality in colleges and universities.

\section{REFERENCES}

[1] Yingchao Guan, Lan Chen and Shibin Xu: Study on the Innovation for Scientific Research Management in Colleges and Universities in the New Situation[J], Journal of Sichuan Normal University(Natural Science), 2010(7).

[2] Zhigang Wang, Xiaoni Zhang and Guohui Wang: Some Thoughts on Improving the Level of Scientific Research Management in Colleges and Universities[J], Management of Agriculture Science and Technology, 2013(2).

[3] Aiping Zheng and Dongliang Zhang: The Synergy Mechanism in University Research Administration Based on Business Process Reengineering[J], Science Research Management, 2016(8).

[4] Xiaojun Lu and Guoli Dong: Study on Quality Training of Research Management Personnel in Universities[J], Experimental Technology and Management, 2013(1).

[5] Yuwei Ding: Study on Current Status and Countermeasures of Scientific Research Management of B School of A University[D], Jilin University, 2013.

[6] Ningsheng Guo and Chunlong Liu: Research on the Analytic Hierarchy Model of the Quality Assessment of Scientific Research Managers in Universities[J], Science and Technology Progress and Policy, 2014(10). 